\title{
Pegadas de Saci. Ensaio etno-rapsódico a quatro mãos sobre as REPRESENTAÇÕES DE UM MITO
}

Jorge Gonçalves de Oliveira Júnior ${ }^{1}$ Universidade de São Paulo, Dep. de Antropologia

Thiago Vaz

Artista Plástico, Grafiteiro, Marcador de Aparições do Saci Urbano

\begin{abstract}
As diversas transformações simbólicas pelas quais passou o Saci, uma das figuras miticas mais difundidas no território brasileiro, através do tempo e do espaço, motivam este ensaio a quatro mãos, que é o resultado de conversas entre o antropólogo, poeta e escritor Jorge Gonçalves de Oliveira Júnior e o artista plástico e grafiteiro Thiago Vaz sobre os registros das "apariçôes" do Saci Urbano pela região metropolitana de São Paulo. Inspirada na noção de "rapsódia literária" de Mario de Andrade, a forma do texto busca testar as fronteiras entre arte e análise cientifica: uma "etno-rapsódia", que se configura como uma colcha de retalbos de diversos gêneros e narradores, na expectativa de colorir o monocromático ponto de vista da monografia e desafiar ao leitor para que ele produza as suas próprias análises a partir de sua leitura e impressões.
\end{abstract}

Palavras-chave: Saci, etno-rapsódia, gênero literário, grafite, mito.

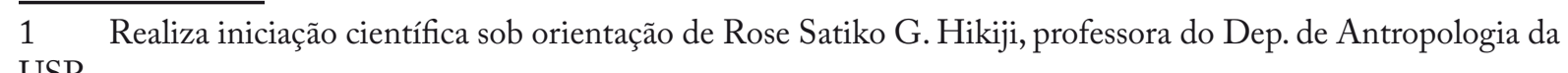
USP. 
"Deus é muito sério, é muito arrogante, é muito mandão. A gente tem que fazer tudo o que ele manda, tem que fazer tudo que ele quer.

Então precisa de um derivativo mais amável, mais benigno, e o Saci é esse derivativo.

Todos esses duendes menores, esses duendes que não tem o que fazer e ficam por aí fazendo arte, eles servem pra deixar a vida assim... um encantatório. A vida tem que ser encantada...

Quem não tem imaginação pra sonhar coisas... Ah... sonha com o Saci!

Então é um mito do encanto.”2

H'bom sempre lembrar que "isto não é um cachimbo" (Magritte 1929). O grafite tem

Eum caráter urbano, intervencionista, ligeiro e efêmero. Por isso o artista-grafiteiro e autor das fotografias que seguem procurou mostrar o "grafite na paisagem" e não o "grafite em si" ou o "grafite e a paisagem"; apenas dessa forma pode-se registrar uma sensação aproximada do encontro do Saci Urbano de maneira súbita, no meio de um trajeto cotidiano (e aqui, no meio da leitura).

O Saci Pererê é uma das figuras mitológicas mais difundidas no território brasileiro e há diversas versões de vários estudiosos que buscaram encontrar sua genealogia ${ }^{3}$. Ele pode ter nascido de um mito indígena que depois foi embaralhado com elementos africanos e europeus, há quem o compare ao Matintaperera ${ }^{4}$, ou o Saci-Ave, pássaro popularmente considerado de mau agouro e cujo canto estridente não permite identificar sua exata localização; mas há também quem o identifique com o Fradinho da Mão Furada, lenda portuguesa, espécie de duende familiar, de gorro vermelho e que rouba a brasa do fogo no furo que trás em uma das mãos - característica presente em alguns relatos sobre o Saci. Sua imagem já foi mais diversa e os relatos mais antigos o identificavam como um pequeno demônio que aproveitou uma festa no inferno e fugiu para a Terra, dessa forma, ele traria chifres, um cheiro forte de enxofre e suas ações, apesar de nunca levarem ninguém à morte, trariam muito azar para as pessoas envolvidas. Atualmente, os elementos demoníacos foram eliminados, principalmente graças à obra infantojuvenil de Lobato (2005) que, devido ao grande sucesso, incluindo adaptações para a televisão, contribuiu para a padronização da figura do Saci como o negrinho de uma perna só, brincalhão, mas sem maldade, cujos poderes emanam de seu gorro vermelho e que se locomove como um rodamoinho. Da mesma forma, além da origem demoníaca já citada, duas outras versões, menos tétricas, contribuíram para a popularização do mito: em uma delas o Saci é um menino escravo que preferiu cortar uma perna para se ver livre dos grilhões; na outra, como entidade mágica, os

2 Depoimento de Dona Ruth Guimarães Botelho, escritora, poetisa e caipira de Cachoeira Paulista (Andrade 2010).

3 A descrição que se segue resume narrativas colhidas e descritas em Benedito (2007), Cascudo (1999), Lobato (1998) e Queirós (1987).

4 Tapera naevia, ave encontrada do México à Argentina ; seu canto assemelha-se sonoramente à palavra "Saci" ou "Sem Fim", como ela também é popularmente conhecida. 
Sacis nasceriam, em dias de vendaval, de dentro de um gomo de taquaruçu ${ }^{5}$, em uma ninhada de sete para viver depois setenta sete anos e morrer transformando em urupê. ${ }^{6}$

Mesmo com tudo isso, as variações desse mito continuam se manifestando e se multiplicando.

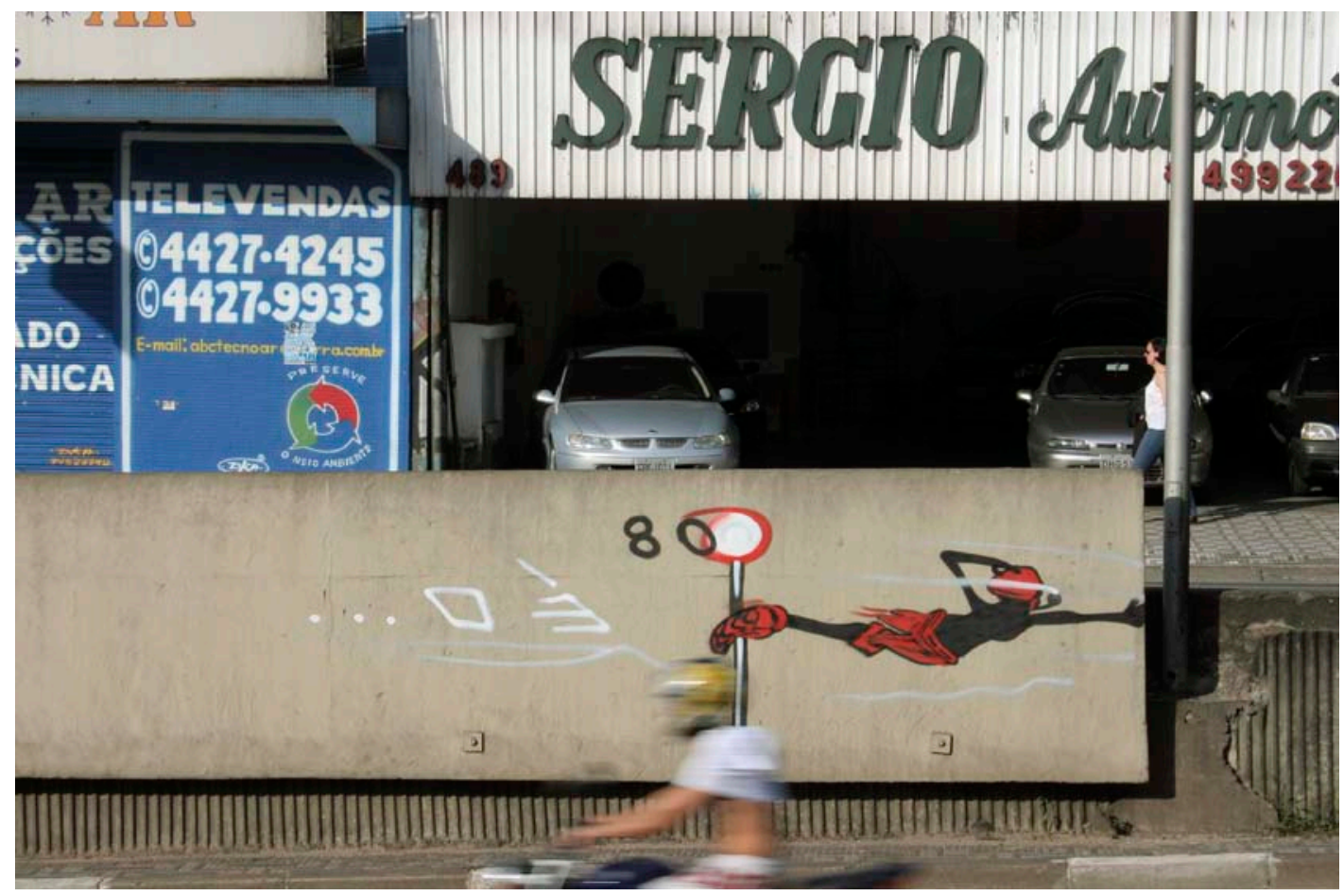

Avenida Perimetral, Município de Santo André, SP. ${ }^{7}$

"Eu subverto o velho adágio e afirmo: acredito em bruxas, porque elas não existem. Porque «existir», no sentido físico, científico, cético, nem mesmo os próprios físicos sabem direito o que é. A matéria é feita de pequenas partículas? De estalos de energia? De cordas vibratórias? De membranas sotopostas? Qual é a última teoria?

Eu fico com o meu avô, homem religioso, sério, sisudo, que me relatou sua experiência ao avistar um lobisomem. Ele no alto de seus 94 anos, e eu na minha soberba dos 16 tive a coragem de sorrir do seu relato. Pois ele olhou nos meus olhos e disse: «Isso é sério! Não se ria! Eu não falo por enigmas! Vi o bicho assim como te vejo agora!» $\mathrm{E}$ eu fui me arrepiando de um medo inexplicável, coisa que não sentia desde a infância. E seus olhos cavados de avô cresceram, se avolumaram, se impuseram e me soterraram, me deixando com o sorriso amarelo de neto paulista que pensa que sabe tudo e não sabe nada. Eu que acredito em átomos que nunca vi, como posso desacreditar do lobisomem que meu avô viu e juramentou? Lobisomens não existem? Mas eu tenho certeza de que Vô Severo viu um.

Era um bicho alto e majestoso, com pelos brancos luminosos. E não era de matéria que se pegasse, era feito de luz do luar. Bem no caminho da casa para o sítio, em lugar ermo, habitado

5 Chusquea gaudichaudii, espécie de bambu, também conhecido como "bambu gigante".

6 Polyporus sanguineus, espécie de cogumelo, também conhecido como "orelha de pau".

7 Todas as fotos deste artigo foram produzidas pelo artista Thiago Vaz (Vaz 2011) e estão disponíveis em seu sítio na internet (http://eosaciurbano.org/) protegidas por uma licença de uso não comercial creative commons. 
por visagens. Mas meu avô não retardou nem acelerou o passo. Colocou seu coração no colo da virgem, rezou o credo e gritou: «Quem pode mais que Nosso Senhor Jesus Cristo? Por baixo, por rente ou por riba da terra?» Pois o licantropo, que estava bem no meio do seu caminho, estacou, escancarou os dentes com gestos sincopados e desengonçados, se curvou até o tamanho de um cachorrinho branco de madame, debandou estrada afora e nunca mais foi visto.

Boa história essa do meu avô. Melhor se contada ao redor de uma fogueira, em sexta feira de lua cheia, com vento morno soprando no mato por trás de nós. Assim escrito, mesmo com adjetivos, perde a sustança.

Mas eu não quero contar essa história que contei. Quero falar de outro duende. Quero falar de Saci."

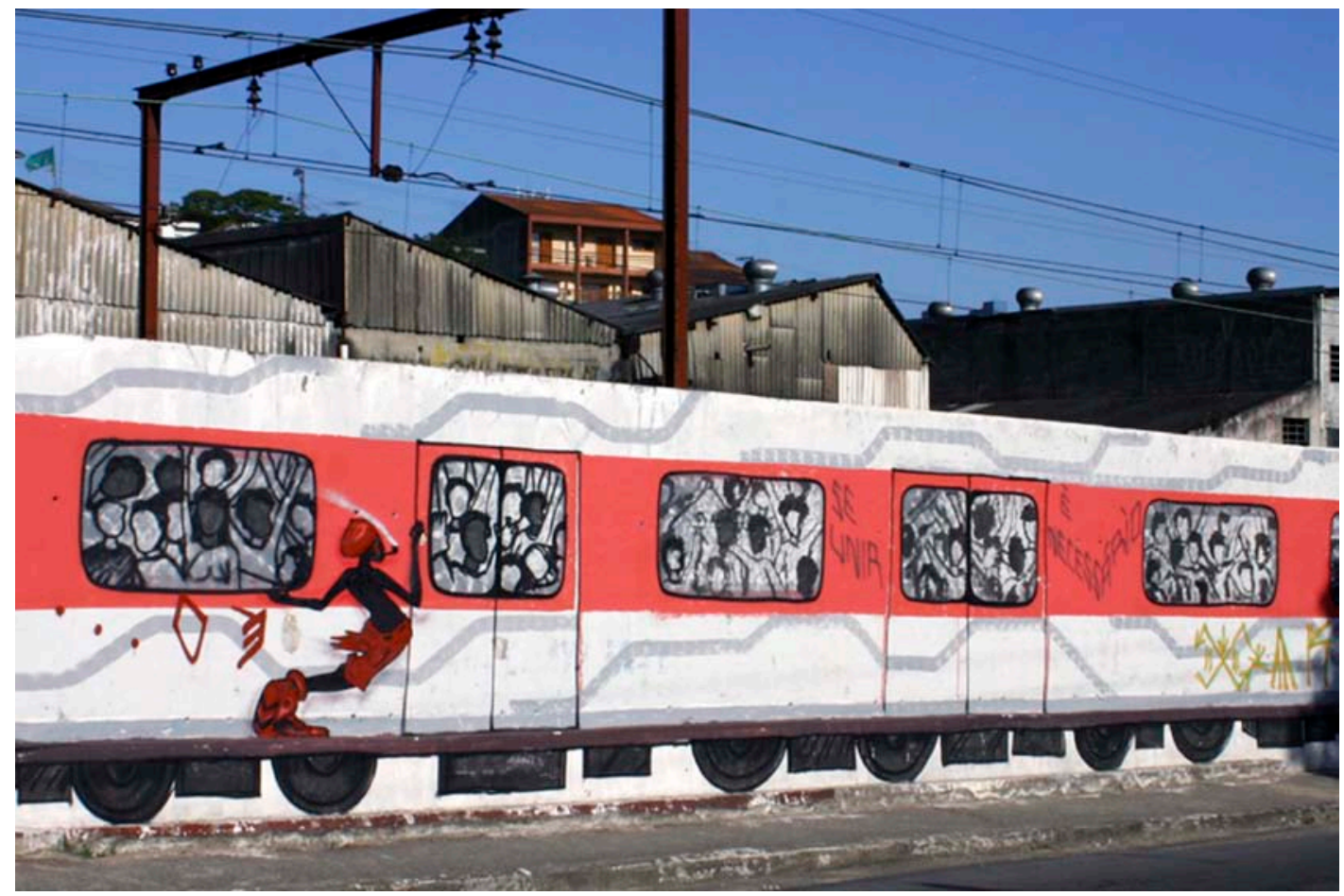

Muro da Companhia Paulista de Trens Metropolitanos (CPTM).

Thiago Vaz não se considera o autor do projeto Saci Urbano, apesar de sê-lo, mas um "marcador de aparições", certa vez Jorge de Barros sugeriu a realização de uma intervenção e a resposta dele, via e-mail, foi:

"Vou pautar essa marcação, já que você viu uma aparição, cabe a mim fazer o trabalho «sujo» (risos)."

Há uma brincadeira entre os artistas e intelectuais divulgadores e defensores do Saci, uma atitude zombeteira, sacisística, de tratar o mito como real, surpreendendo assim os desavisados que ainda não conhecem as regras desse jogo. Trata-se de um esforço de originalidade, pois o caipira, de cujo universo o Saci realmente faz parte, utilizava o mito para entender, explicar

8 Excerto do conto "De Lobisomens e Sacis" (Barros 2010).

$9 \quad$ E-mail de 20 de outubro de 2011. 
e criar relações no seu próprio mundo, conforme ensina o professor Levi Strauss (2005). Logo, conscientemente ou não, os "sacizeiros", na necessidade de resgatar legitimamente e anticapitalisticamente o Saci, ou seja, em sua essência e não apenas aparência, revestem seu discurso na frágil afirmação da sua existência. Isso é fácil de observar no nome das principais associações culturais criadas para preservar o mito: a SOSACI (Sociedade dos Observadores de Saci) e a ANCS (Associação Nacional dos Criadores de Saci) - grifos meus.

Logo, resgatar apenas a figura e a simbologia não é suficiente, o "verdadeiro" Saci enquanto entidade cosmológica, precisa ser completamente resgatado, é necessário que ele receba "crença”. Mas há limites para esse resgate - se é que é possível resgatar um mito - a modernidade e seu processo de racionalização e secularização do mundo pode ser um caminho sem volta, daí que tal ato se reveste de boa intenção, mas não pode se configurar plenamente. Tão logo o interlocutor entende o jogo, logo se esforça em expressar: "Ah, claro, também acredito no Saci”, e mesmo aderindo ao discurso, continuam ambos "acreditando", apenas entre aspas.

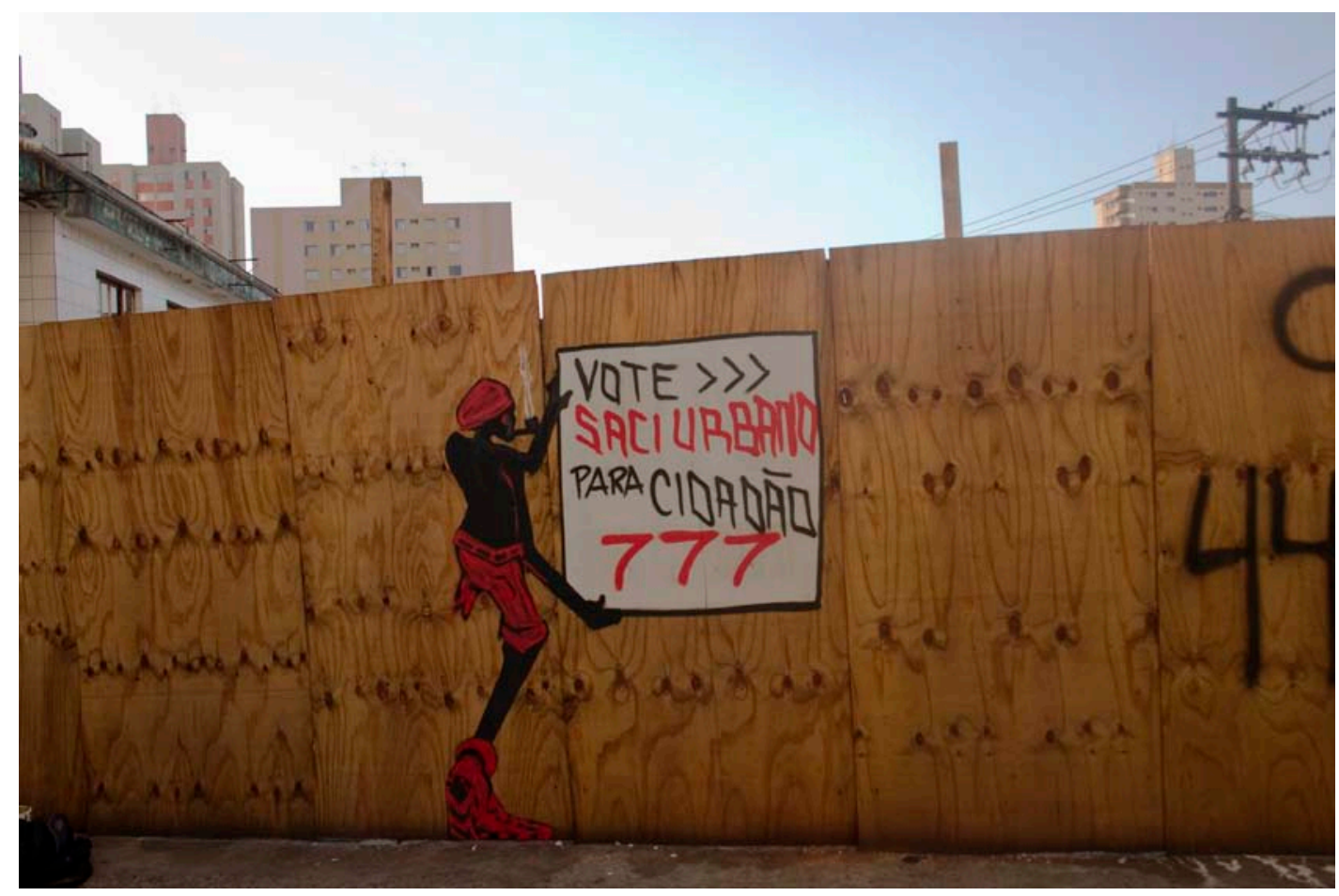

Município de Santo Andre, Av. Santos Dumont.

"Eu comecei com esse trabalho, não assinando, ou seja, eu queria estar anônimo, eu só queria estar à margem pra ver a reação do público. E é até perigoso porque tem gente que chega em alguns lugares e fala «Pô, é você que faz o Saci Urbano!». Comecei fazendo à noite, então ninguém sabia quem que fazia o Saci.

Eu estava fazendo sem permissão mesmo, ou seja, intervenção, mas muitos desses pontos eram em patrimônios públicos. E o que é que isso "patrimônio público»? É um patrimônio público! A gente paga, tem o direito de intervir também. Eu penso assim, a gente tem o direito de intervir porque tá pagando. E se a população tá gostando, então não é mal algum. E o pessoal comenta, no site, muitos não sabem quem é que faz mesmo, no blog, e eu sinto que o pessoal 
quer saber quem é. E aí, quando eu percebi que tava tendo uma repercussão, aí eu percebi, ou eu fico anônimo, ou eu me apresento pra não ter problemas com direitos.

Eu sou Thiago Vaz, eu sou um marcador de aparições do Saci Urbano.

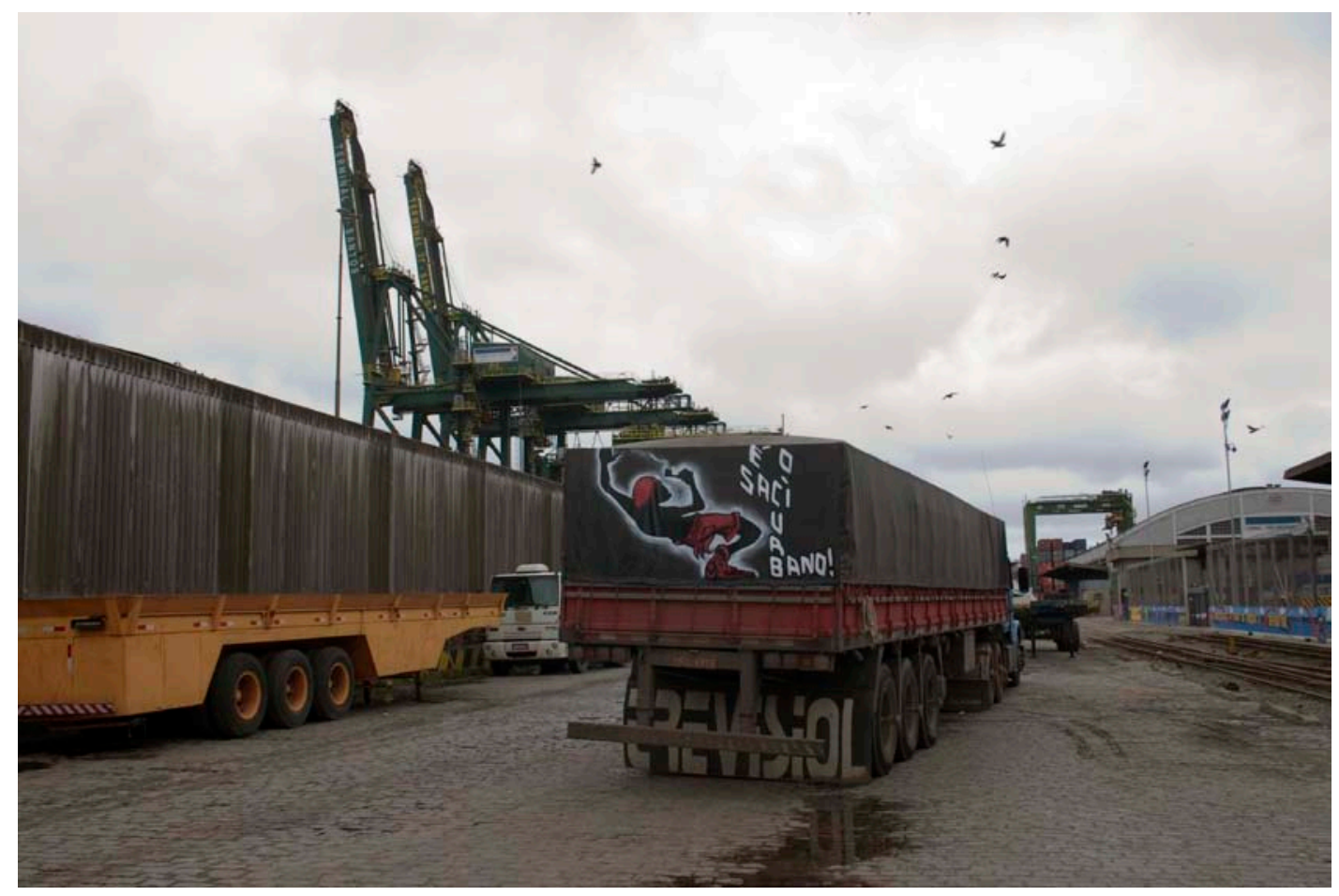

Porto de Santos.

Eu gosto muito desse espaço da rua, porque ele atinge tudo o que é público. O jornal você tem que comprar, então tem que ter uma cultura de leitura e muitos não tem essa cultura, então não se interessam muito pelo jornal, mas na rua, andando de ônibus, a pé, de carro, enfim, ele tá vendo, então é uma coisa muito direta, então eu acho que tem um alcance muito amplo pras pessoas.

Esse é meu projeto do Saci Urbano com o resgate do folclore popular e agora estou apresentando essa nova série do trabalho que é o Saci anti-herói, ou seja, expulsando todos os heróis de outros países que vêm tentar roubar nossa cultura brasileira.

Por que isso? Porque quando a gente assiste filmes norteamericanos, ou seja, de outros países, ele vem dublado, de tanto assistir você começa a se identificar com a cultura daquele filme que, muitas vezes, é de outros países. Mas na verdade tá deixando de lado a sua cultura a sua tradição, da cultura brasileira, dos seus ancestrais, antepassados e começando a viver uma cultura que não é nossa.

Eu me perguntei: «pô, cadê o Saci? Onde é que ele tá? Eu não vejo mais ele em revistas, em livros, na televisão, nada. Onde é que ele tá?» Até na internet eu não achei. Eu falei, ah, deixa eu 
retomar essa coisa do folclore popular, e eu também já estava buscando grafites com referência da cultura brasileira e da cultura afro também. E aí eu vi que o Saci representava tudo isso."10

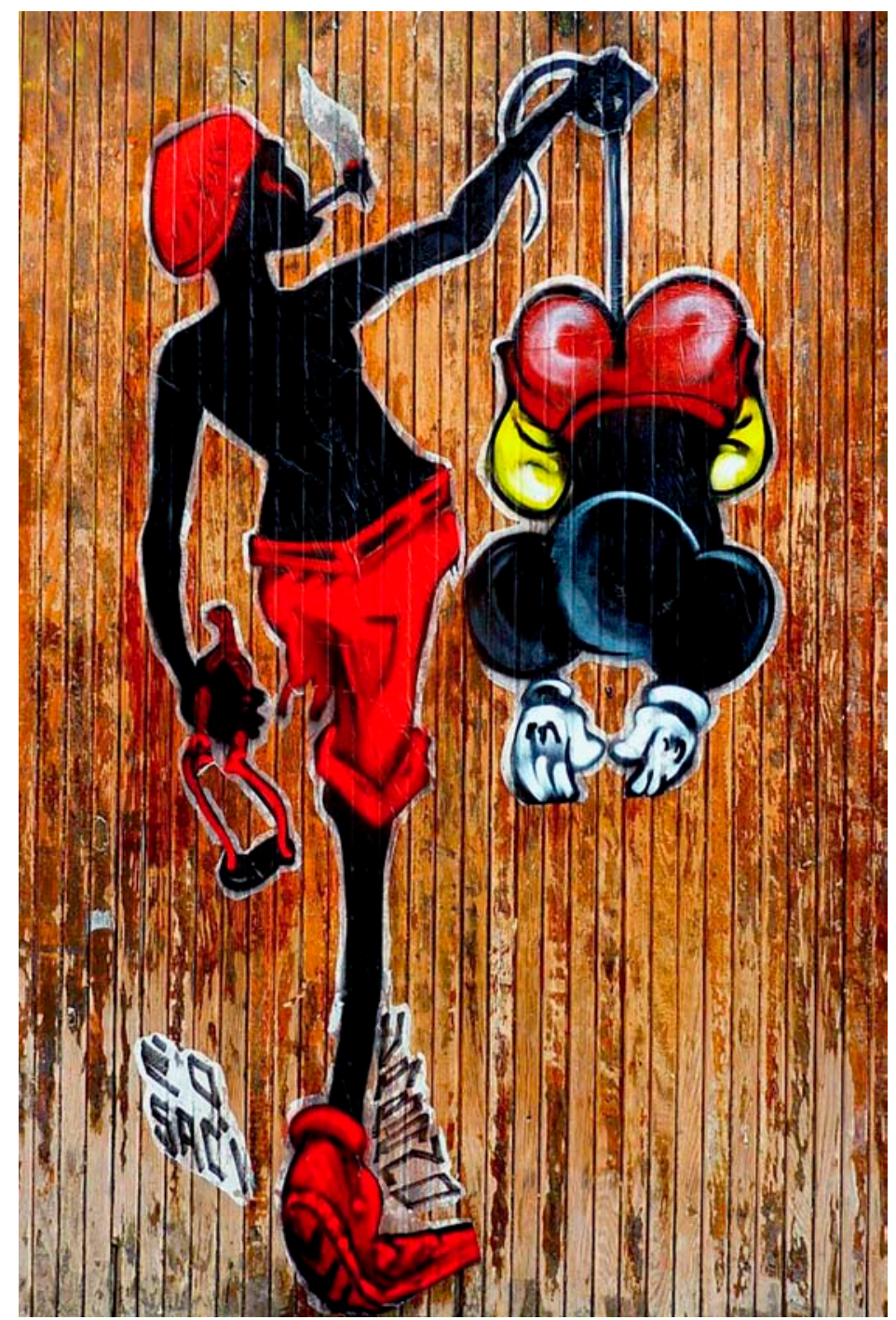

Paris, França.

"Estava eu viajando num famigerado ônibus intermunicipal, em direção ao Jardim Itapeva, em Mauá-SP, quando ouvi uma conversa entre o motorista e o cobrador. Falavam de um grafite de Saci desenhado no muro de uma casa na Avenida dos Estados, em Santo André. O motorista jurava que o artista era o próprio Saci e que em uma madrugada tinha visto o tal, pulando numa perna só, fazendo seu autorretrato pelas ruas da cidade. Achei curioso ouvir aquela história de matuto num coletivo urbano cercado de concreto e asfalto por todos os lados, olhei pra fora e vi o tal do desenho do Saci, com os dizeres: «É o Saci Urbano!» e, mais adiante outra, e outra... Passei a perceber em vários cantos do $\mathrm{ABC}$ e até em São Paulo o ilustre perneta representado em várias poses e atividades: Saci ciclista, skatista, futebolista e até em algumas situações de crítica social: dando comida aos pobres, relatando o consumismo, denunciando a má distribuição de renda, e sempre usando um tênis maneiro no seu único pé. Era um trabalho hercúleo espalhar o ícone do Saci por toda a metrópole! Seria trabalho de um único indivíduo? Seria mesmo

10 Relato de Thiago Vaz. Disponível em Rubio 2010. 
obra desse nosso moleque perneta de gorro vermelho, que tanto encantou Monteiro Lobato? Mordido pela curiosidade, resolvi investigar.

Por meio da world wide web, fonte de pesquisa dos preguiçosos, descobri espantado que a maior autoridade em sacis no Brasil é uma associação situada em São Luiz do Paraitinga, a SOSACI - Sociedade dos Observadores de Saci, uma entidade que abrange artistas e intelectuais de vários segmentos. Pensei se tratar de uma brincadeira, mas lendo os relatos e o estatuto da entidade, lembrei do meu avô e apaguei o riso que já começava a nascer na minha cara. Resolvi contatá-los. Depois de alguns e-mails e telefonemas, consegui algumas informações sobre o tal Saci Urbano por meio de uma reveladora entrevista com um dos eminentes estudiosos do tema: um saciólogo. Entretanto, como o estudo sistemático do Saci ainda sofre muito preconceito, principalmente entre a comunidade acadêmica, o meu informante pediu para não ser identificado, pois se trata de importante professor da uma universidade federal, que já sofreu represálias por defender publicamente a causa do Saci. Por isso, seu nome será omitido e o chamarei apenas de 'saciólogo'.

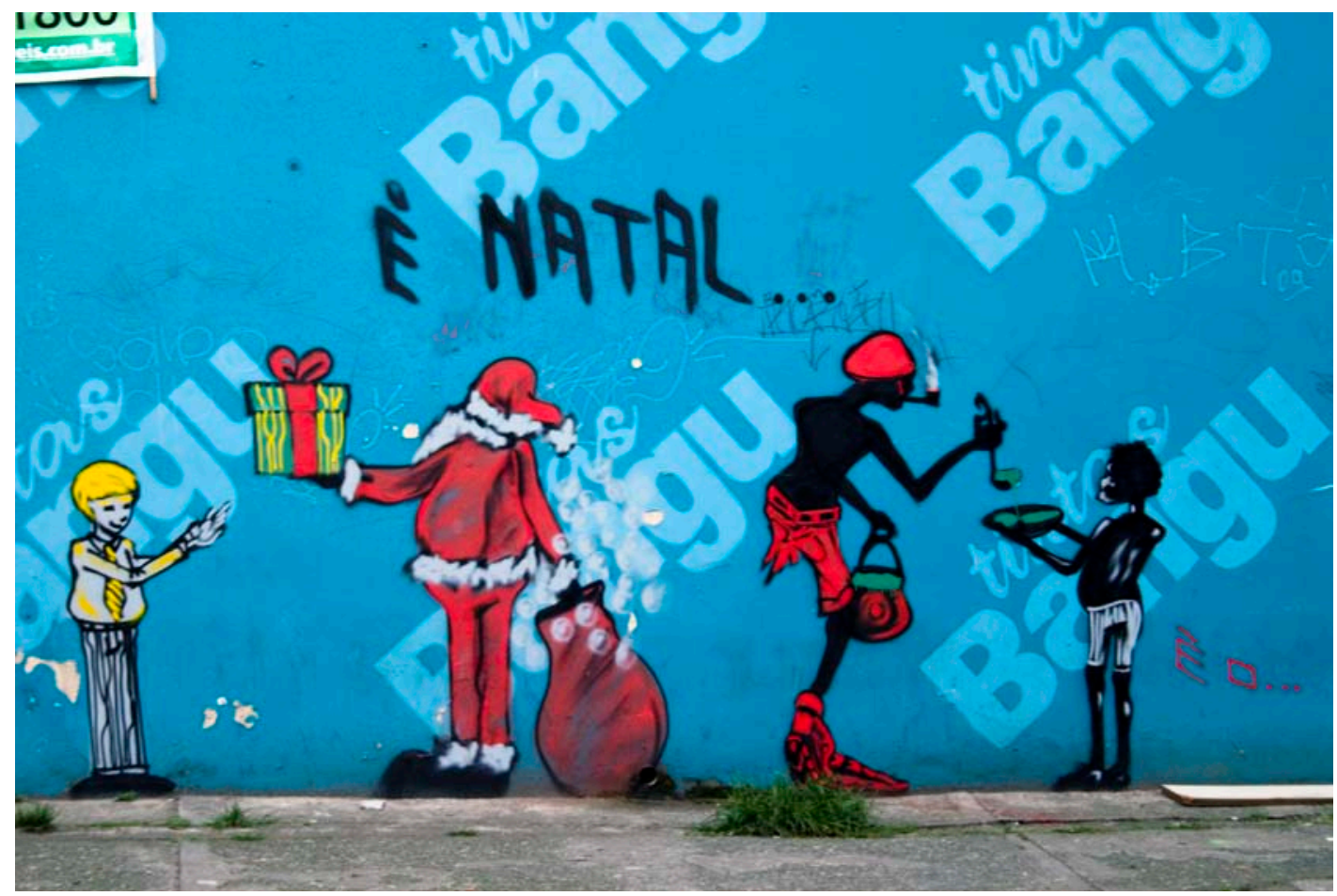

Município de Mauá, SP.

\section{Jorge de Barros: Sacis existem ?11 $^{11}$}

Saciólogo: Posso assegurar que sim, eles existem. Há muita coisa que a ciência não explica e, veja bem, os irlandeses não acreditam em elfos? Há até casos em que estradas foram desviadas para preservar certas pedras onde habitam as tais criaturas mágicas. Então por que nós não devíamos acreditar no Saci? Quer dizer, elfos na Irlanda é cultura, Saci no Brasil é superstição? Isso é pensamento de colonizado! Em algumas regiões do Brasil sua presença é marcante no cotidiano do homem do campo e o Saci é responsabilizado por uma série de fenômenos físicos como a perturbação em alguns animais, os famosos nós na crina dos cavalos, o leite ficando

11 Entrevista ficcional. 
azedo, a pipoca não estourando. É um espírito brincalhão que leva as coisas de um lugar para o outro e desafia a nossa seriedade e a nossa lógica pré-estabelecida das coisas. Aliás, quando me perguntam se o Saci existe, eu prefiro responder com um "por que não?". Por que não acreditar? Que prejuízo levamos em acreditar no Saci?

\section{JdB: É porque a gente vive num mundo marcado pelo raciocinio lógico e pela técnica...}

Saciólogo: Por isso mesmo! Acreditar no Saci é ir contra muita coisa "lógica e técnica" que tem por aí e que só causam horror e barbárie! O Saci é como uma criança, o Saci é completamente pacífico e, por mais que ele crie problemas, nunca é para fazer o mal. O Saci é uma força caótica, e esse tipo de força foi esquecido por este mundo. Veja agora essa campanha da Sosaci, pro Saci ser a mascote da copa ${ }^{12}$. Tem um monte de gente argumentando que não e eu já ouvi um monte de absurdo dos que se dizem contrários. Dizem, por exemplo, que ele não pode ser a mascote porque ele é deficiente, tem uma perna só, sugerem que seja mascote das paraolimpíadas. Veja só, isso é pura discriminação! Se a mascote é um urso, um cachorro, tudo bem, mas urso e cachorro não praticam esporte nenhum, que eu saiba! Então o urso pode e um moleque com uma perna só não pode? É uma mentalidade tacanha! E quando falam do pito! Ah, não pode porque ele fuma, é politicamente incorreto. Mas o Saci é justamente isso, ele ri da cara do politicamente correto, esse politicamente correto está deixando o mundo chato, insuportável. Os jovens estão cada vez mais aceitando ideias como pena de morte, racismo, xenofobia, você viu aquela moça do twitter, aquela estudante de direito massacrando os nordestinos? Ela é só uma menina! E é o tipo de gente que não acredita em Saci, que acha que o fumante deve ser massacrado e que o deficiente só pode representar deficiente. Contra esse mundo é que eu acredito no Saci.

\section{Jdb: Mas você acha que o Saci tem chance de ser mascote?}

Saciólogo: Eu estou nessa campanha, já divulguei bastante, mas ontem mesmo eu estava pensando: quer saber? Toda essa parafernália técnica das competições formais, toda essa burocracia da CBF, tudo isso é anti-Saci. Eu acho mesmo que o Saci deve estar se lixando pra ser ou não escolhido. Acho até que ele vai aprontar bastante durante os jogos. Escreve o que eu estou te dizendo: todas as falhas que acontecerem, as gafes e coisa e tal, pode colocar na conta do Saci, ele vai aprontar muito durante os jogos. E já está atrasando muito estádio por aí com suas traquinagens.

\section{JdB: E quanto ao Saci Urbano?}

Saciólogo: Isso é uma coisa maravilhosa, a capacidade de adaptação do Saci. Mas para explicar isso a gente tem que entender que existem várias espécies de Saci...

\section{JdB: Várias espécies?}

Saciólogo: Sim, tudo o que vem da natureza é assim, variado, multiforme, o Saci não é diferente. Tem por exemplo o menorzinho, que é o Saci-Trique, que anda pela floresta pisando em folha seca e fazendo o barulhinho: "trique-trique", já o Saci comum mede em torno de 77 $\mathrm{cm}$ e anda em forma de redemoinho, mas o Saci que vemos se adaptar melhor à cidade é o Saci-Açu, o maior da espécie, que pode ser confundido com um ser humano de estatura baixa a mediana.

\section{JdB: Esse é o Saci que vem se adaptando?}

Saciólogo: Sim, essa espécie parece ser mais resistente à poluição e é muito adaptável. A 
aparição mais notável vem ocorrendo na periferia de São Paulo e na região do ABC, curiosamente a região mais urbanizada do Brasil, mas já há relatos de Saci Urbano no Rio de Janeiro, Belo Horizonte, Brasília e Recife, agora, os saciólogos ainda divergem sobre se é uma nova espécie, o Saci Urbanus, ou apenas uma variedade de Saci-Açu.

JdB: É justamente sobre o Saci do ABC que eu queria perguntar. É um Saci que anda enchendo a cidade de grafites?

Saciólogo: Olha, isso é uma questão interessante. O artista que faz as obras não é um Saci, é o Thiago Vaz, que mora numa região limítrofe entre a área urbana e a mata atlântica, numa cidade chamada Ribeirão Pires. É um artista plástico muito talentoso, mas não se pode mexer com o Saci e sair incólume...

\section{JdB: Como assim?}

Saciólogo: Veja, nas cidades em que tem aparecido a arte do Thiago, nas proximidades dos desenhos, dos muros, há relatos de aparições de Saci ou coisas estranhas acontecendo. O Saci Urbano parece que está aprendendo a conturbar as redes urbanas. Semáforos que pifam, redes de computador que não firmam ou que caem a toda hora, já tem gente colocando a culpa no Saci. Um amigo meu de São Paulo disse que sua internet vivia caindo, era intermitente, trocava de operadora, mas não adiantava, contei pra ele a história do Saci Urbano, então ele passou a colocar um pouco de fumo de corda no poste da sua casa, uma oferenda ao Saci, e ele nunca mais teve problema.

\section{JdB: Sério?}

Saciólogo: Juro! Mas parece que cigarro do Paraguai também funciona (risos). O próprio Thiago já me contou algumas coisas, como a forma de trabalho dele. Não é sempre que ele consegue fazer o Saci Urbano e não é em todo o lugar, ele relata uma espécie de transe... Há por exemplo alguns desenhos que ele não se lembra de ter feito, há relatos de desenhos feitos em pontos muito distantes que aparecem na mesma noite num trajeto que seria quase impossível que o Thiago tivesse feito a pé, que é a forma como ele trabalha.

\section{JdB: Pode ser uma brincadeira de Saci?}

Saciólogo: Ou uma parceria, sinto mais como uma parceria. Tem um Saci na Cidade Universitária, na USP também, na rua do matão, mas não sei se ele pode ser classificado como urbano, porque ele vive na pequena área verde que tem por lá. $\mathrm{O}$ fato é que ele vem fazendo cada vez mais incursões pelo ambiente urbano, ele toma conta de um grupo de capivaras que vive entre a Cidade Universitária e o poluidíssimo Rio Pinheiros, uma família de capivaras que convive de maneira notável naquele ambiente degradado. Parece que esse Saci arredio vive uma luta contra a cidade e quer trazer a floresta de volta, mas não dá ainda pra saber. Há quem diga que não é o Saci, porque eles não se envolvem nessas causas sérias, há quem diga se tratar de uma caipora, mas não dá pra afirmar nada ainda.

\section{JdB: Última pergunta: você já viu um Saci?}

Saciólogo: Claro que sim! Sacis são muito comuns por todo o Brasil. Mas você tem que se propor a vê-los. Eles são muito danados. Difícil de ver no mato é onça. Onça e uirapuru. Saci é fácil."13

13 Excerto do conto “De Lobisomens e Sacis”(Barros 2010). 


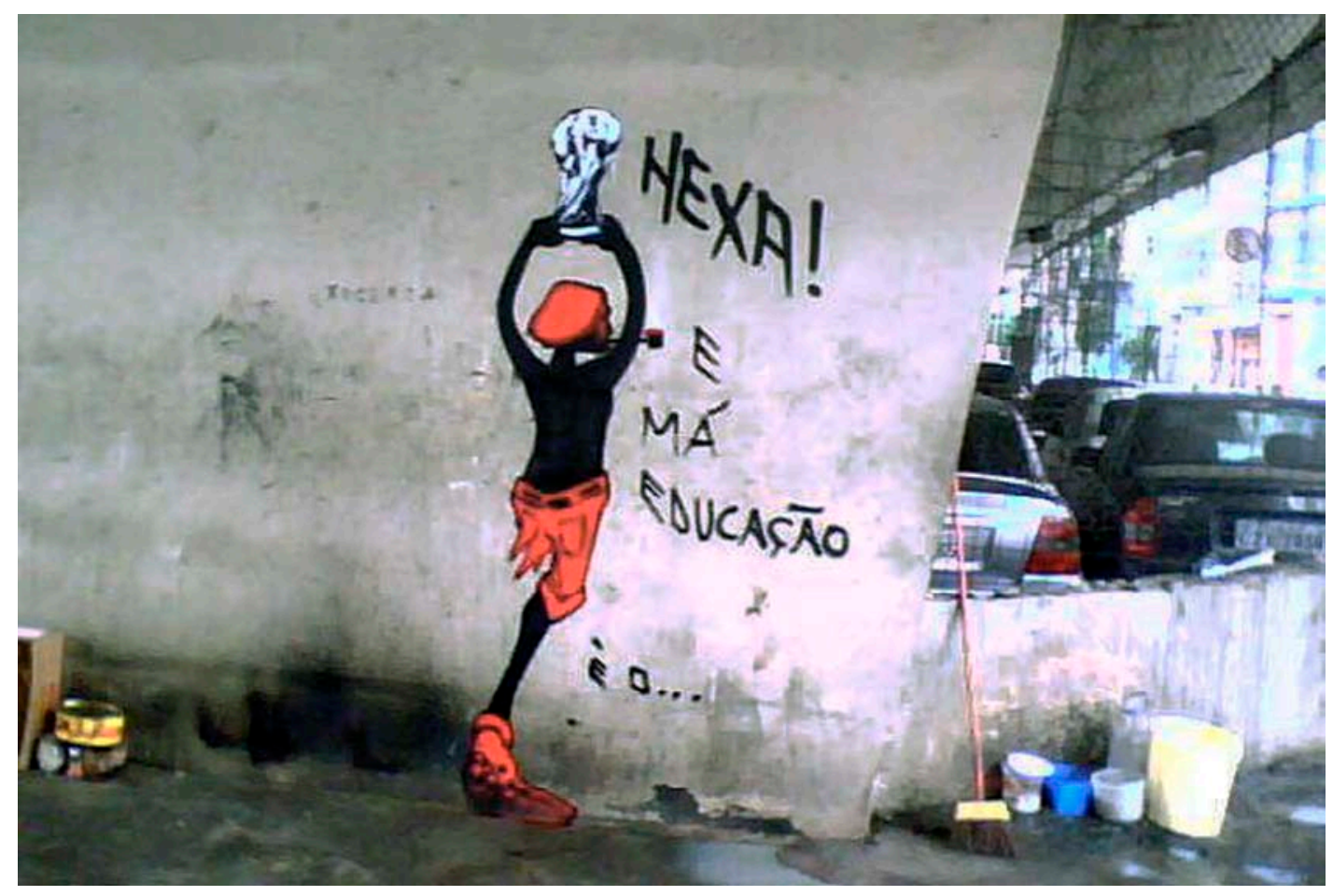

Viaduto na Av. 9 de julho, São Paulo.

"Como os super-heróis, desde muitas décadas, têm uma presença muito forte aqui com vários jovens; eu inclusive tive brinquedos do super homem, homem aranha, esses personagens que vêm de fora.

E o Brasil não tem herói. Mas por que não tem herói? Vamos criar um herói então. Talvez o Saci Urbano possa ser um herói.

O Saci, pra mim, representa o libertário, por isso que ele tem que tá na rua solto. E ele não pode ser vendido, nunca ele vai ser comercializado. Ele é uma representação do brasileiro por isso que eu uso isso como um símbolo brasileiro.

Porque ele tem, na mistura dele, o cachimbo do índio, começou com um menino indígena, e depois migrou pro filho de uma escrava que perdeu a perna. Ele quis tirar a perna pra poder viver solto porque ele tava preso pelos grilhões, e viveu solto na mata. E também tem aquela coisa de liberdade, dos portugueses, os europeus davam a carapuça vermelha pra simbolizar que aquele não era mais escravo, tava liberto.

Eu me sinto incomodado com essa imposição, principalmente dos Estados Unidos, porque eles são imperialistas e esse é o motivo de eles serem imperialistas, porque eles usam o lúdico para impor uma cultura.

Desde que não perca a cultura brasileira, o seu patrimônio cultural imaterial pode, sim, absorver novos fragmentos da cultura européia, norte americana e de diversos outros lugares.

Então o Saci, quando dá estilingada, ele tá chamando atenção pra essa imposição, para essa influência da cultura e, ao mesmo tempo, ele meio que tá querendo tomar um espaço. 
Mas o Saci, por mais que ele tenha uma perna só, ele não vai conseguir extinguir todos os super heróis daqui." 14

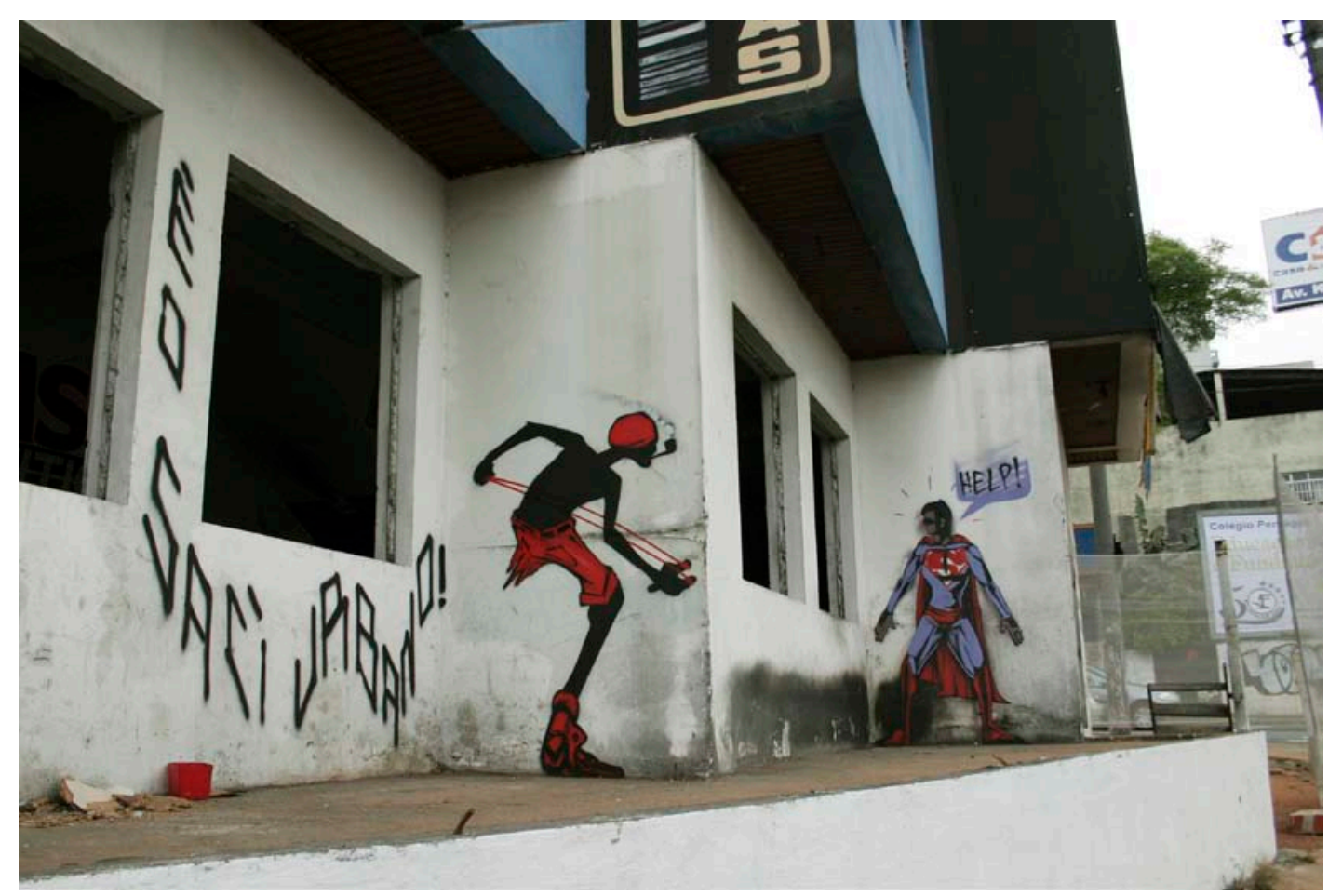

Município de São Bernardo do Campo, SP.

Vieira (2009) analisou de maneira aprofundada as metamorfoses culturais do mito do Saci, o que ela chamou também de assepsia de sua imagem: do diabrete fugido do inferno, com traços animalescos, chifre e cheiro de enxofre, protagonista de histórias de assombração do caipira do Vale do Paraíba, para a figura lobatiana de intenção e forma nacionalista, negrinho traquinas com poderes mágicos, nascido no mato, amigo das crianças e capaz de figurar na literatura infantil; e agora o Saci foi enquadrado num contexto global, dentro de um discurso antiimperialista e como símbolo de uma cultura legítima que é preciso resgatar e preservar. A perda irremediável da crença deixa um vazio, mas que pode ser substituído, entre outras coisas, pela ideologia política. A luta bem sucedida pela oficialização do dia 31 de outubro como Dia do Saci e a campanha, em pleno curso, da nomeação do Saci como mascote da Copa do Mundo FIFA de 2014 mostram essa nova vocação do negrinho de uma perna só, ou melhor, mostram como cada época, com suas demandas culturais e políticas, seu sentimento de estar no mundo, seu ethos, traduz os mitos de acordo com suas necessidades subjetivas.

Podemos fazer até mesmo um paralelo com a figura globalizada do Vampiro, que assim como o Saci também teve suas metamorfoses de representação: o monstro mitológico foi estilizado por Bram Stocker e se tornou metáfora dos desejos sexuais “demoníacos" e animalescos mal reprimidos na Inglaterra vitoriana do séc. XIX, para depois expressar as lutas pelas afirmações identitárias e da contracultura a partir dos anos 70 do séc. XX, principalmente em Anne Rice e, agora, com a atual onda de histórias de vampiros jovens, após uma esmerada "assepsia", para usar o termo de Vieira (2009) tornaram-se seres sentimentais dotados de uma moral cristã

14 Relato de Thiago Vaz. Disponível em Rubio 2010. 
politicamente correta, vampiros "bonzinhos" muito mais vendáveis para crianças e adolescentes (Brina 2009).

Mas isso já é uma outra estória.

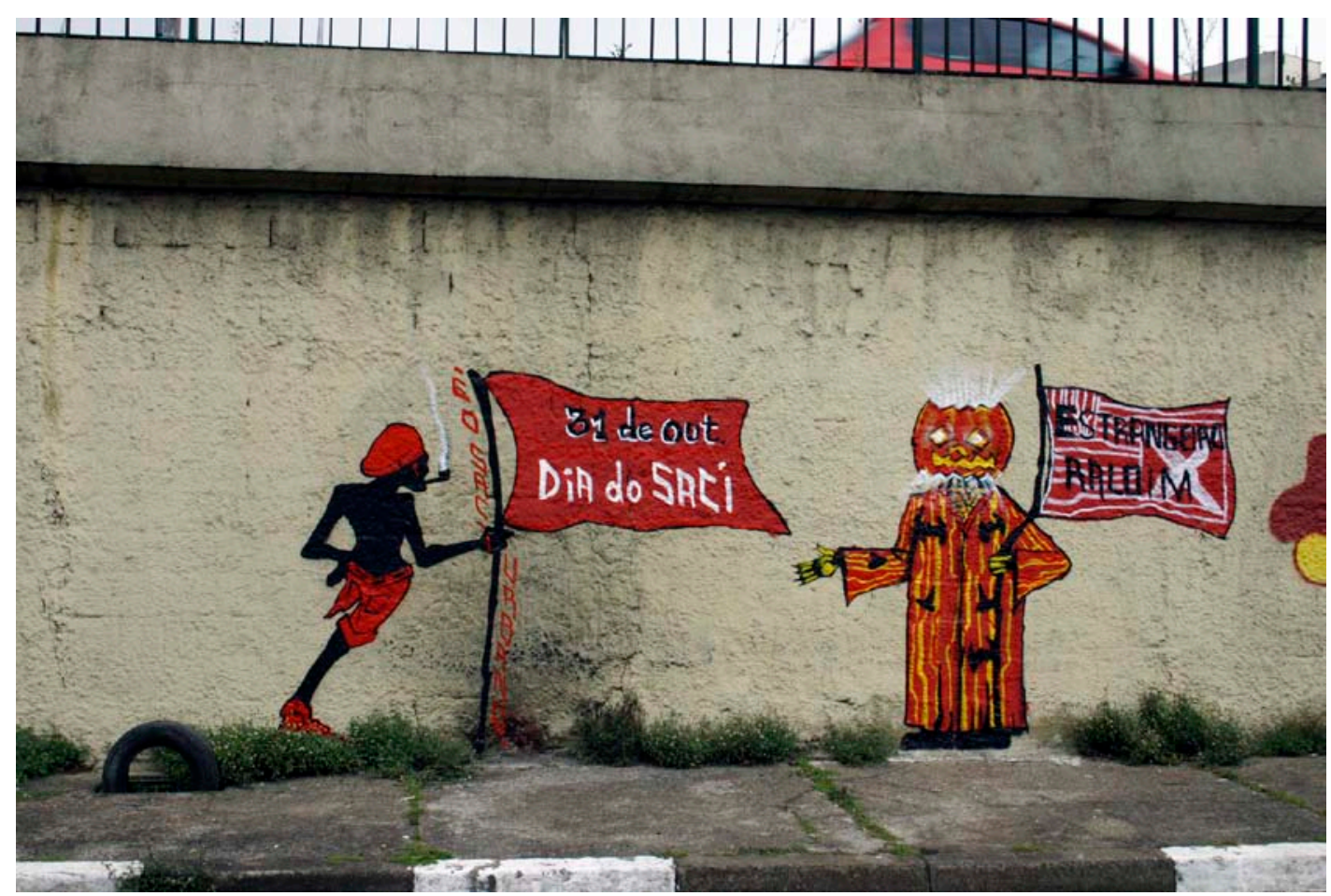

Bairro Boa Vista (próximo ao Bixiga), São Paulo.

\section{Os Três Pulos do SaCl ${ }^{15}$}

fugi do inferno

vivo no oco do mundo

os homens são meus brinquedos

escravo bicho maldição pesadelo

Sem-Fim!

renasci no taquaral

vivo no sonho dos meninos

sou uma lenda de pano

duende moleque reinação brinquedo

Sem-Fim! Sa-Ci!

pulei pras ideologias

vivo no sonho dos homens

sou antiimperialista

símbolo mascote reação política

Sem-Fim! Sa-Ci! Sem-Fim!

o mundo gira-gira ele é meu rodamoinho

15 Etnopoesia à guisa de conclusão. 


\title{
REFERÊNCIAS
}

Andrade, Mário de. 2008. Macunaíma: o herói sem nenhum caráter, Rio de Janeiro: Agir. Andrade, Rudá K. Sylvio do Amaral Rocha. 2010. Somos Todos Sacy. Vídeo, 57'. Confraria Produções. Acesso em Outubro 25, 2011 (http://vimeo.com/11609651).

Barros, Jorge de. 2010. "De Lobisomens e Sacis”. O Oficio do Ócio. Acesso em Outubro 25, 2011 (http://ooficiodoocio.blogspot.com/).

Benedito, Mouzar. 2007. Saci - o Guardião da Floresta. São Paulo: Editora Salesiana. Benedito, Mouzar. 2008. "Saci - Mascote da Copa de 2014”. Revista Fórum. Acesso em Outubro 25, 2011 (http://www.revistaforum.com.br/conteudo/detalhe_materia. php?codMateria=3567).

Brina, Ana Claudia. 2009. "A Identidade Cultural do Vampiro nos séculos XIX, XX e XXI". Recanto das Letras. Acesso em Outubro 25, 2011 (http://www.recantodasletras.com.br/ ensaios/1699396).

Cascudo, Luís da Câmara. 1999. Dicionário do Folclore Brasileiro. São Paulo: Global.

Lévi-Strauss, Claude. 2005. O Pensamento Selvagem. São Paulo: Papirus.

Lobato, Monteiro. 1998. O Sacy Pererê: Resultado de um Inquérito. Rio de Janeiro:Gráfica JB. Lobato, Monteiro. 2005. O Saci, São Paulo: Brasiliense.

Magritte, René. 1929. La Trahison des Images. Pintura, óleo sobre tela. Los Angeles, CA: Los Angeles County Museum of Art.

Mauss, Marcel. 2006. Sociologia e Antropologia, São Paulo: Cosac\&Naify.

Queiroz, Renato da Silva. 1987. Um Mito Bem Brasileiro. Estudo Antropológico Sobre o Saci. São Paulo: Editora Polis.

Rubio, Daniel A. 2010. Thiago Vaz o Saci Urbano. Vídeo, 6:17’. Arver.com Produções. Acesso em Outubro 25, 2011 (http://www.youtube.com/watch?v=19ZWDEwfzW8).

Vaz, Thiago. 2011. São Paulo: “É o Saci Urbano!”. Acesso em Outubro 25, 2011 (http:// eosaciurbano.org/).

Vieira, Maressa de Freitas. 2009. "O Saci da tradição local no contexto da mundialização e da diversidade cultural”. Dissertação de doutorado. USP/FFLCH, Departamento de Letras Clássicas e Vernáculas (http://www.teses.usp.br/teses/disponiveis/8/8142/tde-22022010145342/en.php).

\section{FoOtPRINTS OF SACI. A FOUR-HANDED ETHNO-RHAPSODICAL ESSAY ON THE REPRESENTATIONS OF A MYTH.}

\begin{abstract}
The various symbolic transformations in which the Saci, one of the mythical figures most widespread in Brazil, passed through time and space motivate this essay for four hands, which is the result of conversations between the anthropologist, writer and poet Jorge Gonçalves de Oliveira Junior and the artist and graffiti artist Thiago Vaz and records of the "apparitions" of the Urban Saci through the metropolitan region of São Paulo. Inspired by the notion of "literary rhapsody" by Mario de Andrade, seeks to test the boundaries between art and scientific analysis: an "ethno-rhapsody", which constitutes a patchwork of different genres and writers, hoping to colorize monochrome view of the monograph and challenge the reader to it to produce their own analysis from bis reading and printing.
\end{abstract}

Keywords: Saci, ethno-rhapsody, literary genre, graffiti, myth. 